\title{
UROLOCIA EN IMACENES
}

\section{"Fístula reno-duodenal en el contexto de un tumor renal."}

Xavier Ruíz Plazas, Antoni Vicenç Vicenç, Fernando García Montes, José Miguel Morón Canís y Mariano Ozonas Moragues.

Servicio de Urología. Hospital Universitari Son Dureta. Palma de Mallorca. Servicio de Cirugía'. Hospital Universitario Son Dureta. Palma de Mallorca. España.

\section{D} aciente varón de 49 años diagnosticado de masa renal de polo superior derecho de $10 \times 10 \times 11.5 \mathrm{~cm}$. cavitada y llena de gas con contenido intestinal por fistulización a duodeno (Figura 1), múltiples adenopatías para-aórticas e hiliares y múltiples nódulos pulmonares bilaterales con afectación pleural. Se propuso intervención quirúrgica paliativa con el fin de evitar posibles complicaciones secundarias a la evolución natural de la enfermedad, realizándose nefrectomía ampliada derecha con linfadenectomía regional e interaortocava, resección parcial duodenal, sutura y exclusión completa del duodeno mediante cierre con TEA post-pilórico y gastroyeyunostomía transmesocólica.

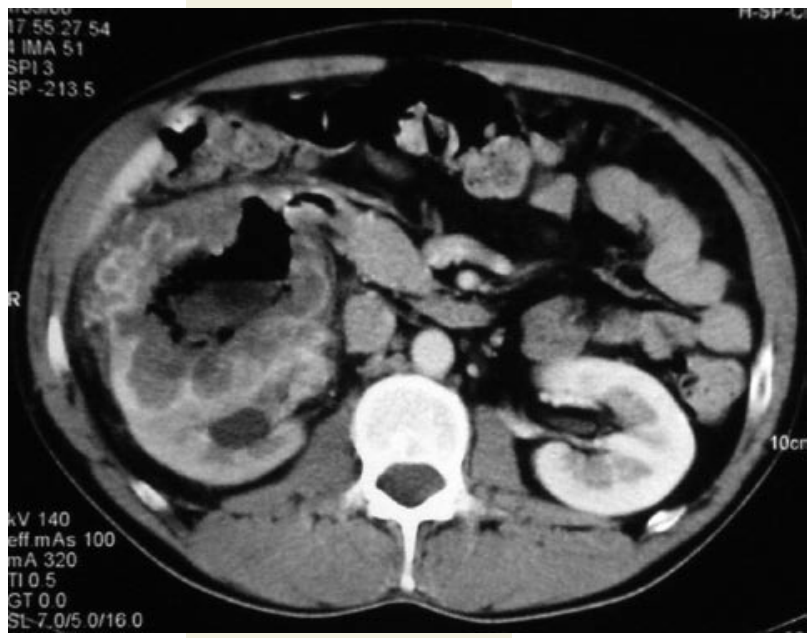

FIGURA 1.TAC abdomino-pélvico: Masa renal derecha que infiltra rodilla duodenal. Se observa la fístula con el paso de gas y contenido intestinal al riñón.

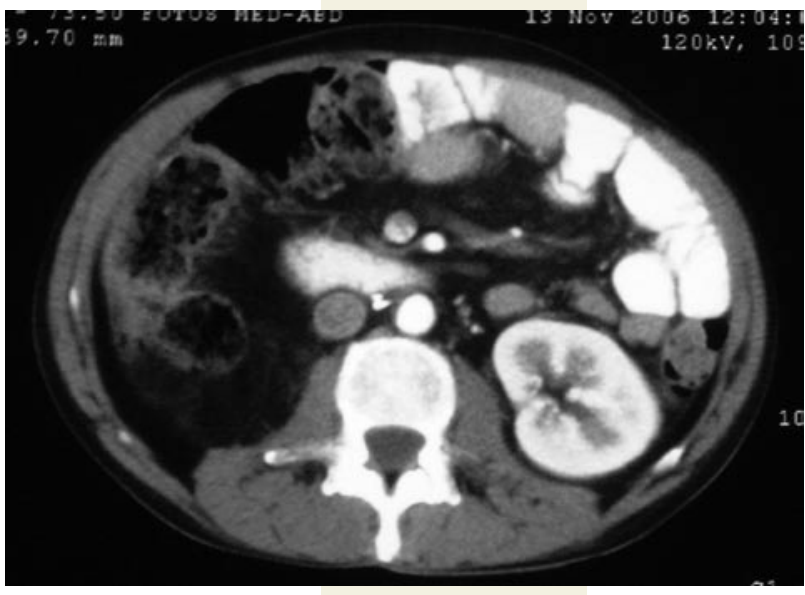

FIGURA 2. TAC abdomino-pélvico 4 semanas tras la intervención. Lecho quirúrgico sin imágenes sospechosas residuales. Duodeno y gastroyeyunostomía permeables sin signos de extravasación.

El posterior informe de anatomía patológica informó de carcinoma renal de células claras y segmento duodenal con signos de peritonitis aguda $y$ fibrosis sin invasión tumoral. La Figura 2 muestra el TAC post-operatorio que confirma estanqueidad de las suturas intestinales y la ausencia de masas residuales. En la actualidad el paciente se encuentra en tratamiento activo de sus metástasis pulmonares con sunitinib.

Xavier Ruíz Plazas

Servicio de Urología

Hospital Universitario Son Dureta

Andrea Doria, 55

07014 Palma de Mallorca. (España). xarupl@gmail.com 